\title{
INJUNCTIVE RELIEF AGAINST CAMPUS DISORDERS
}

\author{
ROBERT R. ROSENTHAL †
}

\begin{abstract}
If indeed Courts of Equity did not interfere in cases of this sort, there would (as has been truly said) be a great failure of justice in the country. ${ }^{1}$
\end{abstract}

Student occupations of campus buildings, sit-in demonstrations, and other campus disorders occur with increasing frequency throughout the country. Because these disorders are often destructive and costly, as well as disruptive of academic life, college administrators have sought effective means for controlling them. Attempts to prosecute for criminal trespass have for the most part been dismal failures. They require that the police enter a campus when tensions are highest, and the resulting confrontations between police and the student demonstrators only aggravate a crisis situation by "radicalizing" moderate students.

At the urging of social and legal critics, university administrators have turned to the courts in search of injunctive relief. In contrast to the criminal trespass approach, the notable successes of injunctions have made them a popular legal remedy against campus disorders. An injunction restrains demonstrators from conducting themselves in a manner that would "disrupt or interfere with normal functions" of the university, and prevents them from "employing force or violence" against persons or property on the university campus. ${ }^{2}$ If the order is

$\div$ A.B. 1961, LL.B. 1964, Columbia University. Law Assistant to the Board of Justices, Supreme Court of New York, Queens County.

12 J. Story, EQUity JURISPRUdEnce $\$ 1258$, at 610 (14th ed. 1918). The statement is made in the context of the author's discussion of the extension of the jurisdiction of courts of equity to cases of repeated trespasses.

2 Board of Higher Educ. v. SDS, 60 Misc. 2d 114, - 300 N.Y.S.2d 983, 985 (Sup. Ct. 1969). The order to show cause containing the temporary restraining order in this case was signed on April 21, 1969. It provided.:

ORDERED that pending the hearing of this motion, the defendants and all other persons receiving notice of this injunction be and they hereby are restrained and enjoined:

1. From congregating or assembling within any of plaintiff's academic or administrative buildings, recreation rooms or athletic facilities or in any corridors, stairways, doorways and entrances thereto on the campus of Queensborough Community College, in such manner as to disrupt or interfere with normal functions conducted by plaintiff in such place or to block, hinder, impede or interfere with ingress to or egress from any of such properties by plaintiff's faculty, administrators, students, employees or guests thereat;

2. From creating or broadcasting on plaintiff's Queensborough Community College campus or in the streets adjacent thereto, any loud or excessive 
obeyed, a cooling-off period replaces a hostile confrontation and provides a greater opportunity for administrators and students to resolve their differences peacefully. A court may even be able to interpose itself as a third force between students and administrators and become, in effect, an overseer of campus events and a mediator of disputes. No criminal remedy seems capable of producing such a result.

Even if the injunction is not obeyed, the remedy of a contempt citation will in many cases be preferable to criminal proceedings, since the contempt penalty is less severe ${ }^{3}$ than the penalties for the offenses likely to be committed during campus demonstrations.

Considering the growing use of injunctions in campus disputes, a legal analysis of their employment is appropriate. This Article examines some of the problems in this novel application of equity relief, including justification for the exercise of equity jurisdiction, the protection of individual constitutional freedoms, and procedural difficulties.

\section{Equitable Principles}

It is a settled rule that under certain circumstances equity will enjoin a continuous trespass. ${ }^{4}$ Characterized in one leading treatise as "now firmly established in its principles," 5 this basis for equitable jurisdiction has been similarly described by another commentator:

Formerly indeed Courts of Equity were extremely reluctant to interfere at all, even in regard to cases of repeated trespasses. But now there is not the slightest hesitation if the acts done or threatened to be done to the property would be ruinous or irreparable, or would impair the just enjoyment of the property in future. ${ }^{6}$

Most of the cases granting injunctive relief against continuous trespasses, however, are far removed factually from campus disorder cases. They have involved restraints against: encroachment caused by

noise that hinders, impedes, prevents or interferes with the conduct of normal activities by members of the College community;

3. From employing force or violence, or the threat of force or violence, against persons or property on plaintiff's Queensborough Community College campus;

4. From inciting or counselling others or conspiring with others to do any of the above-mentioned acts.

This order to show cause is on file at the office of the County Clerk, Queens County. 3 See, e.g., N.Y. Judictary LAw \$\$ 750-51 (McKinney, 1968), as amended, (McKinney Supp. 1969); PA. STat. ANn. tit. 17, \$\$2047-48 (1962); Tex. Rev. Civ. Stat. ANN. pt. 6, \$ 5, rule 692 (1955); WASH. REv. Code ANN. $\$ \$ 7.40 .150,7.40 .160$ (1961); Wis. Stat. AnN. $\$ 256.06$ (1957).

4 See generally Annot., 60 A.L.R.2d 310 (1958); Annot., 32 A.L.R. 463 (1924).

54 J. Pomeroy, EQuity Jurisprudence $\$ 1357$, at 964-65 (5th ed. 1941).

62 J. Story, Equity Jurisprudence $\$ 1258$, at 610 (14th ed. 1918). 
an adjoining landowner's buildings or other structures, ${ }^{7}$ injuring trees or mines, ${ }^{8}$ diverting or polluting streams, ${ }^{9}$ trespasses by railroads, ${ }^{10}$ and trespasses on railroad property. ${ }^{11}$

\section{A. School and Church Property}

More similar to campus disorder cases are the cases granting injunctive relief against continuing trespasses on school or church property. Mendenhall v. School District No. $83,^{12}$ for instance, is a quaint forerunner of the present applications for relief by school officials. In that case the defendant, under claim of ownership, "removed the fence

7 See, e.g., Harrison v. Lee, 253 Ala. 543, 45 So. 2d. 705 (1950) (injunction denied, but continuous trespass doctrine affirmed by the court) ; Morley v. Berg, 216 Ark 562, 226 S.W.2d 559 (1950) (court upheld right of state attorney general to seek injunction to prevent continued illegal taking of sand and gravel from beds of navigable rivers) ; Fairrington v. Dyke Water Co., 50 Cal. 2d 198, 323 P.2d 1001 (1958) (injunction granted prohibiting maintenance of sign on plaintiff's property) ; Baron v. Korn, 127 N.Y. 224, 27 N.E. 804 (1891) (injunction lies to restrain defendants from erecting a wall on plaintiff's property); Seufert Bros., Co. v. Hoptowit, 193 Ore. 317, 237 P.2d 949, cert. denied, 343 U.S. 926 (1951) (defendant enjoined from entering plaintiff's land for the purpose of carrying on commercial fish business). See generally $1 \mathrm{~J}$. High, INJUNCTIONS $\$ 704$, at 675-77 (4th ed. 1905).

8 E.g., West Point Iron Co. v. Reymert, 45 N.Y. 703 (1871); Choctaw Lumber Co. v. McKeever, 119 Okla. 282, 249 P. 712 (1926); Webber v. Offhaus, 135 W. Va. 138 , 62 S.E.2d 690 (1950); cf. Whitaker v. Langdon, $302 \mathrm{Ky} .666,195$ S.W.2d 285 (1946). See generally $1 \mathrm{~J}$. High, Injunctions $\$ 724$, at $688, \$ 730$, at 693 (4th ed. 1905) ; 2 J. StORY, EQUTTY JURISPRUDENCE \$ 1259, at 611 (14th ed. 1918).

${ }^{9}$ E.g., Strobel v. Kerr Salt Co., 164 N.Y. 303, 58 N.E. 142 (1900); Amsterdam Knitting Co. v. Dean, 162 N.Y. 278, 56 N.E. 757 (1900); Henicle v. Pennsylvania R.R., 49 Ohio App. 447, 197 N.E. 360 (1934).

10 E.g., Lambert v. St. Louis \& G. Ry., 212 Mo. 692, 111 S.W. 550 (1908); Garvey v. Long Island R.R., 159 N.Y. 323, 54 N.E. 57 (1899) ; Lynch v. Metropolitan Elevated Ry., 129 N.Y. 274, 29 N.E. 315 (1891) ; Henicle v. Pennsylvania R.R., 49 Ohio App. 447, 197 N.E. 360 (1934); McClung v. Sewall Valley R.R., 97 W. Va. 685, 127 S.E. 53 (1925).

11 See generally 42 AMr. Jur. 2D Injunctions \$153, at 912 (1969). The diversity of cases to which the doctrine of injunctive relief against continuous trespass has been applied is well illustrated by the decision in Potomac Elec. Power Co. v. Congress of Racial Equality, 210 F. Supp. 418 (D.D.C. 1962). In an action for a permanent injunction plaintiff-public utility alleged that defendant had threatened to distribute stamps or pasters to the utility's customers who would affix them to the return stub of the utility's bill to prevent them from being processed by the utility's calculating machines. Holding that injunctive relief was warranted, the court stated that one of the traditional functions of a court of equity is to enjoin a continuous trespass where irreparable injuries are threatened and the award of damages would not be adequate. Similarly, in Lucy Webb Hayes Nat'l Training School v. Geoghegan, 281 F. Supp. 116 (D.D.C. 1967), the court, enjoining a patient from refusing to leave a hospital when requested, stated:

It has been established for a great many years that equity will enjoin a continuing trespass or a series of repeated trespasses where an action for damages would not be an adequate remedy. There is a leading English case on that point, London \& Northwestern Railway Co. v. Lancashire \& Yorkshire Railway Co., Law Reports 4 Equity Cases 174, 179. The Supreme Court has approved and enforced this doctrine on many occasions, Watson v. Sutherland, 5 Wall. 74, 79, 18 L. Ed. 580; Donovan v. Pennsylvania Co., 199 U.S. 279, 304, 26 S. Ct. 91, 50 L. Ed. 192; Archer v. Greenville Sand \& Gravel Co., 233 U.S. $60,65,34$ S. Ct. 567,58 L. Ed. 850.

Id. at 117.

1276 Kan. 173, 90 P. 773 (1907). 
which enclosed the schoolhouse grounds, removed the outhouses and piled them against the school building, plowed up the ground, [and] planted it in corn . . . ."13 The Supreme Court of Kansas upheld both the temporary restraining order and the permanent injunction granted by the lower court. It stated that " $[w]$ here the injuries inflicted by a trespass are of a continuing kind, or injurious to growing trees or other property for which damages would not compensate, injunction will lie." 14 Since Mendenhall had prevented the use of the school for educational purposes, "[n]o mere action for damages would give the district an adequate remedy." 15

A similar situation was presented in School Directors $v$. Toll. ${ }^{16}$ Plaintiff-school district had forbidden defendants to use a school for religious meetings because past meetings had resulted in damage to the building and its furniture. Injunctive relief was sought against the defendants who had forcibly broken into the school, held meetings, and threatened to continue to hold them. The court held that the chancellor had jurisdiction to issue the temporary injunction because "[i]t is obvious that if plaintiffs in error were relegated to the action of trespass numerous suits against the various trespassers would probably be necessary for the protection of their rights in the premises . . . "17

Historically, equity has also acted to enjoin a continuous trespass on church property where the trespass threatens to deprive the trustees and the congregation of the use and enjoyment of the property. For example, in Dowdell v. Cherry, ${ }^{18}$ the Supreme Court of Georgia held that a cause of action was stated in a petition for injunction alleging that the defendants, expelled members of the Daniel Grove Missionary Baptist Church, repeatedly trespassed upon and exercised acts of control over church property, thereby depriving the members of the church of their right to use the church property exclusively for church purposes. The court stated that the allegations "show a wrongful, continuing interference with a right to the exclusive use and benefit of property"

$13 I d$. at $174,90 \mathrm{P}$. at 774.

$14 I d$. at $177,90 \mathrm{P}$. at 775 .

$15 \mathrm{Id}$. at $178,90 \mathrm{P}$. at 775 .

16149 III. App. 541 (1909).

17 Id. at 545. Injunctive relief was also granted to school officials against continuous trespass on school property in the following cases: Independent School Dist. $v$. De Wilde, 243 Iowa 685, 53 N.W.2d 256 (1952) (injunction against defendant who without lawful right laid tile sewer drain in school property); Duffee v. Jones, 208 Ga. 639, 68 S.E.2d 699 (1952) (injunction against defendants who, claiming title under a void deed, were altering school property); Frailey Township School Dist. v. Wetzel, 29 Pa. D. \& C. 607 (Schuylkill C.P. 1937) (township board of road supervisors perpetually restrained from constructing a wall on school property); Glasco v. School Dist. 22, 24 Okla. 236, 103 P. 687 (1909) (injunction against defendant who, acting under claim of title, prevented use of school for school purposes, obstructed ingress and egress, and threatened acts of violence).

18209 Ga. 849, 76 S.E.2d 499 (1953). 
and held that "it is well settled in this jurisdiction that equity will enjoin a continuing trespass." 19

In a similar case, ${ }^{20}$ the Supreme Court of Pennsylvania held that it was proper to enjoin a member of a synagogue from entering its premises where the proof adduced at trial showed that on numerous occasions the defendant had called the Rabbi vile names and had created other disturbances preventing religious services from being conducted. The court stated:

Unless a chancellor protects the plaintiff, it is clear that the congregation will be deprived of the use and enjoyment of its property. In such case, there is no adequate remedy at law for the unlawful acts of the defendant which have been constantly recurring and threaten to continue; and equity clearly has jurisdiction, as declared in numerous decisions of this court, to entertain the bill and enter such decree as will effectively protect the congregation in the use and enjoyment of its property. ${ }^{21}$

The rationale supporting equity jurisdiction in all these cases was clearly stated by the Supreme Court of Wisconsin in Trustees of the German Evangelical Congregation v. Hoessli, ${ }^{22}$ in which the defendants, falsely claiming to be the trustees of the church, were enjoined from interfering with church property:

Now it must be admitted that the circumstances of this case are so special, the nature and use of the property itself are so peculiar, that an ordinary action of trespass would furnish no adequate compensation for an injury to the possession. For would any mere pecuniary damages furnish any compensation to a religious society for repeated and constant acts of trespass upon its property and temporalities? Most clearly not. The entire value of such property consists in its free and undisturbed use and enjoyment for religious worship. Considering, therefore, the nature of this property, the use and purpose to which it is dedicated, the mischief arising from acts of trespass upon it, and the insufficiency of the ordinary legal remedies, we must say that, in our opinion, the complaint states a proper case for an injunction. ${ }^{23}$

19 Id. at 849,76 S.E.2d at 500 .

20 Ashinsky v. Levenson, 256 Pa. 14, 100 A. 491 (1917).

21 Id. at $17,100 \mathrm{~A}$. at 492 .

2213 Wis. 348 (1861).

23 Id at 355 . Other cases involving similar factual situations and reaching identical results include: Christian Church v. Sommer, 149 Ala. 145, 43 So. 8 (1907); Heath v. Butler, 213 Ga. 411, 99 S.E.2d 131 (1957); Trustees of the First Congregational Church v. Stewart, 43 Ill. 81 (1867); Gilbert v. Arnold, 30 Md. 29 (1869); Knox v. Askew, 62 Tex. Civ. App. 217, 131 S.W. 230 (1910). But see Slaughter v. Land, 190 Ga. 491, 9 S.E.2d 754 (1940); German Evangelical Lutheran Church v. Maschop, 10 N.J. Eq. 57 (1854). 


\section{B. Campus Disorders as a Contimuous Trespass}

The conduct of students occupying campus buildings, facilities, or private offices, and either threatening violence or participating in actual destruction of university property, including private files, constitutes a continuous trespass. Applications for injunctions to restrain such conduct qualify for equitable relief under the traditional test requiring as a basis for jurisdiction "the probability of irreparable injury, the inadequacy of pecuniary compensation, and the prevention of a multiplicity of suits . . . "24 Campus disorders which substantially disrupt academic life certainly pose the threat of irreparable injury. ${ }^{25}$ The time lost by both students and professors can never be replaced, and money damages surely is inadequate compensation. Nor can lost or destroyed files or research papers ever be compensated for or replaced. Whatever remedy may exist at law is also inadequate ${ }^{26}$ in light of the necessity for a multiplicity of suits and the knowledge that any relief afforded at law would be for past, not future, trespasses.

The need for equitable relief against campus disorders was expressly recognized in Board of Higher Education v. SDS. ${ }^{27}$ The court rejected the argument that such suits were barred because they had previously never been brought in equity: "It is not a fatal objection to the granting of an injunction that the use of the writ for the particular purpose for which it is sought is novel." 28 Applying the traditional test of equity jurisdiction, the court granted permanent injunctive relief against demonstrators at a community college who had caused substantial destruction of college property after they were notified that the police had arrived to remove them following a three week sit-in at a library-administration building.

Some factual situations may not fall so clearly within traditional equity jurisdiction: for example, if the timeliness of the protest is crucial and its duration is short. A recruiter is scheduled to visit a

$241 \mathrm{~J}$. HIGH, INJUNCTIONs $\$ 697$, at 661 (4th ed. 1905).

25 "An injury is irreparable when it cannot be adequately compensated in damages, and it is not necessary that the pecuniary damage be shown to be great." 43 C.J.S. Injunctions $\$ 23$, at 447 (1945).

$26 \mathrm{Mr}$. Justice Story describes an adequate remedy at law as follows:

It must be adequate; for if at law it falls short of what the party is entitled to, that founds a jurisdiction in equity. And it must be complete; that is, it must attain the full end and justice of the case. It must reach the whole mischief and secure the whole right of the party in a perfect manner at the present time and in future; otherwise equity will interfere and give such relief and aid as the exigency of the particular case may require.

1 J. Story, Equity JuRISPRUdence §33, at 30-31 (14th ed. 1918).

2760 Misc. 2d 114, 300 N.Y.S.2d 983 (1969). (1945)).

${ }^{28}$ Id. at 118,300 N.Y.S.2d at 988 (quoting 43 C.J.S. Injunctions $\$ 18$, at 429 
campus on Friday. To protest the scheduled visit, various student organizations nonviolently sit-in at a campus building on Thursday morning. Classes continue without substantial disruption. Having notified the students of its intention, the college seeks a temporary injunction that afternoon. A court faced with this problem will not easily be able to fit the activities of the protesters within the traditional "continuous trespass" framework outlined above. The occupation will probably not lead to multiple trespass suits, for it will be over in less than twenty-four hours. Nor is it likely to cause irreparable damage. Although use of the building in which the students sit-in may be impeded, no class time is lost by other students. Indeed, the issuance of an injunction might cause irreparable damage to the demonstrators; they would lose the only possible opportunity to make an effective protest. A balancing of the competing interests ${ }^{29}$ in such a case calls for much more delicacy than in the more disruptive encounters considered above, and it is doubtful that an injunction would issue.

Nevertheless, barring such a unique factual context, most campus disturbances, especially those involving actual or threatened violence, will easily meet the requirements for equity jurisdiction.

\section{Injunctions Against Criminal Acts}

A problem is raised by the possibly criminal nature of the demonstrators' actions. Campus disrupters who occupy buildings or destroy university property may be subject to criminal prosecution for their actions. $^{30}$ Although equity does not act to enjoin criminal acts, ${ }^{31}$ this traditional abstention from the exercise of equitable jurisdiction should not defeat an action for injunctive relief against campus demonstrators.

The leading treatises agree that an injunction is never granted solely to restrain criminal acts, because such a grant would usurp the jurisdiction of criminal courts. An injunction will issue, however, where a civil or a property right is invaded by acts only incidentally criminal : ${ }^{32}$

29 See notes $34-49$ infra \& accompanying text.

30 The severity of this problem should not be overemphasized. Occupation of a campus building without more is not a criminal act in most jurisdictions, since criminal trespass statutes exist in only a few states. See L. Schwartz \& S. GoldsteIN, LAw ENFORCEMENT HANDBOOK FOR POLICE 309 (1969).

31 See, e.g., People ex rel. Bennett v. Laman, 277 N.Y. 368, 376, 14 N.E.2d 439, 442 (1938); 1 J. High, INJUNCTIONS $\$ 20$, at 29 (4th ed. 1905); 4 J. POMERoy, EQUITY JURISPRUDENCE \$1347, at 949-50 (5th ed. 1941).

32 Courts recognized early that an injunction will lie to restrain an existing public nuisance, although the nuisance also represents a violation of the state penal laws. Ex parte Wood, 194 Cal. 49, 227 P. 908 (1924); Pompano Horse Club, Inc. v. State ex rel. Bryan, 93 Fla. 415, 111 So. 801 (1927); State ex rel. Crow v. Canty, 207 Mo. 439, 105 S.W. 1078 (1907). But see Hedden v. Hand, 90 N.J. Eq. 583, 107 A. 285 
That a court of equity will not undertake the enforcement of the criminal law, and will not enjoin the commission of a crime is a principle of equity jurisprudence that is settled beyond any question. There can equally be no doubt that the criminal nature of an act will not deprive equity of the jurisdiction that would otherwise attach. . . Whether or not the act sought to be enjoined is a crime, is immaterial. Equity does not seek to enjoin it simply because it is a crime; it seeks to protect some proper interest. If the interest sought to be protected is one of which equity will take cognizance, it will not refuse to take jurisdiction on the ground that the act which invades that interest is punishable by the penal statutes of the State. Equity does not pretend to punish the perpetrator for the act; it attempts to protect the right of the party (here the People) seeking relief, and to prevent the performance of the act or acts, which here may injure many. ${ }^{33}$

Since a court of equity protects the property rights and civil rights injured by a continuing trespass, the criminality of the acts of some campus demonstrators should not defeat this jurisdiction.

\section{Constitutional Principles}

To express opposition to university policies or to the war in Vietnam, student protestors use a variety of tactics, ranging from editorials in campus newspapers to occupation of campus buildings. When this opposition takes the form of a speech or a written editorial, courts have been reluctant to allow university officials to tamper with

(Ct. Err. \& App. 1919) (1916 statute attempting to confer jurisdiction of purely criminal cases on courts of chancery held unconstitutional). Gradually, courts expanded the notion of enjoining acts perhaps also punishable under the criminal law. See, e.g., Dworken v. Apartment House Owners Ass'n, 38 Ohio App. 265, 176 N.E. 577 (1931); Note, The Injunction-A Method of Zoning Enforcement, 15 Syracuse L. REv. 546 (1964). See generally, 2 J. Higr, InJunctions \$ 1415(h), at 1418-19 (14th ed. 1905); J. STORY, EQUITY JURISPRUDENCE $\$ 1217$, at 573 (14th ed. 1918).

Some courts have found a double jeopardy problem in such treatment, People $v$. Lim, 18 Cal. 2d 872, 880, 118 P.2d 472, 476 (1941) (dictum), but most courts have not been bothered by the idea of multiple punishment. See, e.g., Murphy v. United States, 272 U.S. 630 (1926); In re Debs, 158 U.S. 564 (1895); State v. Boren, 42 Wash. 2d 155, 253 P.2d 939 (1953). But see Civil Rights Act of 1964 \&1102, 42 U.S.C. \$2000h-1 (1964) (bars prosecution for criminal contempt following conviction for a specific crime based on the same act).

Another problem raised by an injunction against activity otherwise punishable as criminal is that the defendant may be deprived of his right to a jury trial. In the past, courts have not felt restricted by this possibility, see, e.g., Pompano Horse Club, Inc. v. State ex rel. Bryan, 93 Fla. 415, 111 So. 801 (1927); Developments in the LazInjuictions, 78 HARv. L. REv. 994, 1018-19 (1965) [hereinafter cited as Developments]; Note, The Petty Offense Category and Trial by Jury, 40 YALE L.J. 1303 (1931), but following the Supreme Court's decision in Bloom v. United States, 391 U.S. 194 (1968), a jury trial must now be provided for all "serious" contempt offenses. See notes 82-89 infra \& accompanying text.

33 People ex rel. Bennett v. Laman, 277 N.Y. 368, 376, 14 N.E.2d 439, 442 (1938) (citations omitted). 
the freedom of the dissenter to express his views. ${ }^{34}$ Yet there is no constitutional right to express dissent at any place or at any time. ${ }^{35}$ The state may regulate action accompanying otherwise protected speech, ${ }^{36}$ or expression that creates a "clear and present danger" of a substantive evil that may legitimately be prevented. ${ }^{37}$

For example, peaceful picketing has generally been accorded constitutional protection, but decisions in the Supreme Court ${ }^{38}$ and in the state courts ${ }^{39}$ have held that the right to picket may be restricted under certain circumstances. Similarly, although the Supreme Court in Tinker $v$. Des Moines Independent School District ${ }^{40}$ held that public high school students could not be suspended for wearing armbands to publicize their opposition to the Vietnam war, Justice Fortas' opinion for the Court carefully emphasized that "our independent examination

${ }^{34}$ See, e.g., Dickey v. Alabama State Bd. of Educ., 273 F. Supp. 613 (M.D. Ala. 1967), vacated as moot sub nom. Troy State Univ. v. Dickey, 402 F.2d 515 (5th Cir. 1968). The court reinstated a student who had been forbidden to return to college following his summer vacation because he had written an editorial in the student paper supporting a stand in favor of academic freedom taken by the president of the University of Alabama. Relying on the first amendment (as applied to the states through the fourteenth amendment), the court stated:

A state cannot force a college student to forfeit his constitutionally protected right of freedom of expression as a condition to his attending a state supported institution.

Id. at 618. This statement is consistent with the language of the Supreme Court in Sweezy v. New Hampshire, 354 U.S. 234, 250 (1957): "The essentiality of freedom in the community of American universities is almost self-evident." But see Norton v. Discipline Comm. of East Tenn. State Univ., 419 F.2d 195 (6th Cir. 1969) (court upheld suspension of a student who had distributed a leaflet urging other students to rebel against the school administration).

35 See Adderly v. Florida, 385 U.S. 39, 48 (1966) ; Cox v. Louisiana, 379 U.S. 536 (1965).

36 See O'Brien v. United States, 391 U.S. 367 (1968).

37 Schenck v. United States, 249 U.S. 47, 52 (1919).

38 Teamsters Local 695 v. Vogt, Inc., 354 U.S. 284 (1957) ; cf. Carpenters \& Joiners Local 213 v. Ritter's Cafe, 315 U.S. 722 (1942). See also Cox, Strikes, Picketing and the Constitution, 4 VAND. L. REv. 574 (1951) ; Farmer \& Williamson, Picketing and the Injunctive Power of State Courts-From Thornhill to Vogt, 35 U. Der. L.J. 431 (1958); Samoff, Picketing and the First Amendment: "Full Circle" and "Formal Surrender," 9 LAB. L.J. 889 (1958).

39 Pezold v. Amalgamated Meat Cutters \& Butcher Workmen, 54 Ca1. App. 2d 120, 128 P.2d 611 (1942) (holds that picketing which unreasonably threatens violence or induces fear of physical molestation may properly be enjoined; infers that blocking of entrances and exits to buildings may also be enjoined); Dolan Dining Co.v. Cooks' \& Ass'ts' Local 399, 124 N.J. Eq. 584, 4 A.2d 5 '(1938), rev'd on other grounds, 126 N.J. Eq. 321, 8 A.2d 809 (1939) (company operating lunch wagon can enjoin picketing by union if it interferes with free egress and ingress to the wagon); Springfield, Bayside Corp. v. Hochman, 44 Misc. 2d 882, 255 N.Y.S.2d 140 (1964) (tenants enjoined from picketing landlord); Brown v. Sucher, 258 Wis. 123, 45 N.W.2d 73 (1950) (court held there was insufficient cause for peaceful picketing); cf. Baldwin v. Arizona Flame Rest., 82 Ariz. 385, 313 P.2d 759 (1957) (strike by union may be enjoined if called for illegal purpose); County Court v. West Virginia Air Service, 132 W. Va. 1, 54 S.E.2d 1 (1948) (court granted injunction to prohibit continued use of airport by defendant after county granted that right to a competing service).

The fact that a public building is being occupied does not give the demonstrators an absolute right to protest. People v. Martinez, 43 Misc. 2d 94, 250 N.Y.S.2d 28 (1964).

40393 U.S. 503 (1969). 
of the record fails to yield evidence that the school authorities had reason to anticipate that the wearing of the armbands would substantially interfere with the work of the school or impinge upon the rights of other students." 41 Had the record shown evidence of disruption causing significant impairment of the ability of other students to use the school facilities, it is doubtful that the Court would have reached the same result.

In a somewhat analogous case ${ }^{42}$ preceding Tinker, the Court of Appeals for the Fifth Circuit upheld the suspension of students for wearing freedom buttons to school, where the record indicated that the wearing of the buttons had caused much disruption in the school. Recognizing that freedom of speech is a right easily infringed, the court based its decision on a delicate balancing of competing interests. ${ }^{43}$ The complexity of the problem and the consequent need to scrutinize closely the facts of each case is illustrated by a companion case, ${ }^{44}$ in which the same court, with the same judges sitting, reached the opposite result.

The use of injunctions to halt student demonstrations requires a similar balancing of interests and examination of the facts in each case. A demonstration will probably involve both protected and unprotected activity. Diverse groups may simultaneously be acting lawfully and unlawfully, and a court must carefully mold its decree to fit the facts in order to insure that protected activity is not sacrificed in the desire to reach the unprotected conduct. ${ }^{45}$ The court should preserve opportunities for peaceful expression, yet prohibit the destruction of property. ${ }^{46}$ When more than one group of demonstrators is involved, it may have to tailor its order to fit each group.

In balancing the interests of the demonstrators against the interests of the university, the court should also consider the need for university administrators to regulate the places and times students are allowed to use campus facilities: "The establishment of an educational program requires the formulation of rules and regulations necessary for the

41 Id. at 509 .

42 Blackwell v. Issaquena County Bd. of Educ., 363 F.2d 749 (5th Cir. 1966).

43 Cases of this nature, which involve regulations limiting freedom of expression and the communication of an idea which are [sic] protected by the First Amendment, present serious constitutional questions. A valuable constitutional right is involved and decisions must be made on a case by case basis, keeping in mind always the fundamental constitutional rights of those being affected.

Id. at 753 (footnote omitted).

44 Burnside v. Byars, 363 F.2d 744 (5th Cir. 1966).

45 An injunctive decree may be invalid either because it is overly broad, see Developments 1065 , or because it is excessively vague, see Jaffee, The Judicial Enforcement of Administrative Orders, 76 HARv. L. REv. 865, 885-86 (1963) (distinguishing overbreadth from vagueness).

${ }^{46}$ Cf. Payne v. Johnson, 20 Wash. 2d 24, 145 P.2d 552 (1944). 
maintenance of an orderly program of classroom learning." 47 If a demonstration does not impair the use of campus buildings or facilities by the nondemonstrating portion of the university community, university officials probably cannot constitutionally prohibit it. ${ }^{48}$ But the Constitution would not prevent them from making "a prompt and severe disciplinary response to violence and rioting and other constitutionally unprotected conduct." 49

Several recent cases support this conclusion. In Hutt v. Brooklyn College, ${ }^{50}$ students who had seized and occupied the registrar's office until police were called brought an action to enjoin, inter alia, disciplinary proceedings against them. Holding that their conduct was not constitutionally protected, the court stated:

That the state may, in some cases, constitutionally punish conduct intended to express an idea or point of view, is not open to question. . . . The Supreme Court has often rejected the proposition that "people who want to propagandize protests or views have a constitutional right to do so whenever and however and wherever they please. . . ." The admitted facts of this case indicate a willful trespass on College property, the exclusion of administrative personnel of the College and an intentional refusal by the plaintiffs to end their seizure and adverse holding of College property after being warned that they faced suspension or dismissal and even arrest for violating the rules of the College and the New York State trespass laws.

Even assuming that the aforesaid conduct does combine "speech" elements with "nonspeech" elements, nothing in the First Amendment forbids the State (or College authorities) from disciplining students who prevent others from access to College facilities. . . A reasonable balancing of interests must reserve to the State (and the College) the power to preserve its facilities for their intended uses. The right to communicate does not include the right to confiscate. ${ }^{51}$

Similarly, in Buttny $v$. Smiley, ${ }^{\mathbf{3} 2}$ plaintiffs who had protested the presence on campus of a Central Intelligence Agency recruiter by

47363 F.2d at 748.

48 Cf. Hammond v. South Carolina State College, 272 F. Supp. 947 (D.S.C. 1967) (holding invalid a rule prohibiting "parades, celebrations, and demonstrations" without prior approval of college authorities).

49 Soglin v. Kauffman, 295 F. Supp. 978, 989 (W.D. Wis. 1968).

50 Civil No. 68-C-691 (E.D.N.Y., July 30, 1968).

$51 \mathrm{Id}$. at 30-31 (citations omitted).

62281 F. Supp. 280 (D. Colo. 1968) ; see Barker v. Hardway, 283 F. Supp. 228 (S.D. W. Va.), aff'd, 399 F.2d 638 (4th Cir. 1968), in which the court stated:

True it is that enrollment in school does not mean the student surrenders any of his constitutional rights. But by the same token, that fact does not give 
physically blocking the entrance to the placement service contended that the imposition of disciplinary penalties by the school had a "chilling effect" on their first amendment freedom of speech. The court nonetheless held that the first amendment did not give plaintiffs the right to prevent lawful access to campus facilities. Finally, in Grossner $v$. Trustees of Columbia University, ${ }^{53}$ the plaintiffs who had occupied buildings on the Columbia University campus contended that their occupation was necessary "to breathe life into the First Amendment principle that government institutions should reflect the will of the people [and] that the rhetoric and tactics of the American Revolution are the guides by which judges are to construe the First Amendment." 54 Characterizing these contentions as "at best useless (at worst deeply pernicious) nonsense in courts of law," 55 the court rejected plaintiffs' claims:

It is surely non-sense of the most literal kind to argue that a court of law should subordinate the "rule of law" in favor of more "fundamental principles" of revolutionary action designed forcibly to oust governments, courts and all. But this self-contradictory sort of theory-all decked out in the forms of law with thick papers, strings of precedent and the rest-is ultimately at the heart of plaintiffs' case. And so it is not surprising that plaintiffs' efforts to implement the theory have led them to champion a series of propositions of unsound constitutional law. ${ }^{56}$

Accordingly, in Board of Higher Education v. SDS, ${ }^{\mathbf{5 7}}$ the court, citing Hutt, Butney, and Grossner, held that the issuance of a permanent injunction against activities tending to disrupt the normal functions of a university or to produce violence on the campus did not offend any of the constitutional guarantees provided in the first amendment. 58

More recently, the Massachusetts Institute of Technology obtained a temporary injunction restraining the November Action Coalition, a

him the right to abuse and harass the administrators of the institution or engage in conduct detrimental to its well-being or which may tend to deprive other students of the right to a peaceful atmosphere in which to pursue their ambition for an education . . . I have failed to find any case saying that the right of free speech and peaceful assembly carries with it the right to verbally abuse another or to threaten him with physical harm or to deprive him of his right to enjoy his lawful pursuits.

Id. at 238. See also Scott v. Alabama State Bd. of Educ., 300 F. Supp. 163 (N.D. Ala. 1969) ; Scoggin v. Lincoln Univ., 291 F. Supp. 161 (W.D. Mo. 1968).

63287 F. Supp. 535 (S.D.N.Y. 1968).

$54 I d$. at 545 .

$55 I d$.

$56 I d$.

5760 Misc. 2d 114, 300 N.Y.S.2d 983 (Sup. Ct. 1969).

38 Id. at -, 300 N.Y.S.2d at 991. 
loose organization of approximately thirty antiwar groups, from violence or the threat of violence during a protest against defense research.59 Reluctant to suppress legitimate expression, the university nevertheless felt compelled to protect "the fundamental rights of this institution." 60

These cases clearly indicate that the first amendment does not present an insurmountable obstacle to university administrators attempting to bring peace to a troubled campus. When demonstrators threaten or cause destruction of a university's property or substantial disruption of its basic operations, university administrators may constitutionally secure injunctive relief restraining such conduct.

\section{Procedure to Obtain Injunctive Relief}

Applications for injunctions against campus disorders, and the proceedings to punish for criminal contempt those who disobey the injunctions, create several procedural problems. Because an injunction prohibits certain forms of conduct, it is unlikely to be upheld unless the party enjoined is provided specific procedural guarantees. Moreover, if a party is accused of violating a court order, he is entitled to additional procedural safeguards, since contempt is a drastic remedy ${ }^{61}$ that may lead to incarceration. ${ }^{62}$

\section{A. Ex Parte Restraining Orders}

Prior to the Supreme Court's landmark decision in Carroll $v$. President and Commissioners of Princess Anne, ${ }^{63}$ a plaintiff desiring to secure either a preliminary or permanent injunction could in some states first seek a temporary restraining order, issued ex parte after

59 N.Y. Times, Nov. 4, 1969, at 1, col. 6.

60 Id. 34, col. 5. The president of M.I.T. stated:

Of all the institutions in our society, the university is most nearly defenseless.

It has to be. The university exists so that there may be somewhere a place for the courageous and direct confrontation of ideas. The free flow of ideas cannot take place in an atmosphere of physical confrontation; an open mind cannot long exist in the face of force or threat.

It does not matter where force may come from-from the Legislature, from the police, from the alumni, from outsiders, or indeed, from the administrators. Once force crosses the threshold, the university is diminished.

It is clear to me that ... we cannot ourselves and with only our own resources deal with force or the threat of force. We are vulnerable; we were created vulnerable; and we will remain so as long as we are free.

Id. 34 , col. 3 .

61 "Punishment for a criminal contempt is a drastic remedy for willful wrong."

Spector v. Allen, 281 N.Y. 251, 259, 22 N.E.2d 360, 364 (1939) ; accord People v. De Feo, 308 N.Y. 595, 605, 127 N.E.2d 592, 597 (1955). "When an injunction issues, the possible severity of the penalty for disobedience renders the defendant's freedom of choice virtually nonexistant." Developments 1005.

62 See, e.g., N.Y. Judiciary LaW $\$ 751$ (McKinney Supp. 1969).

63393 U.S. 175 (1968). 
a summary hearing. ${ }^{64}$ But in Carroll the Court held that a ten-day restraining order preventing a "white supremacist" organization from holding a rally must be set aside because of a "basic infirmity in the procedure by which it was obtained" 65_namely, that the order "was issued ex parte without notice to petitioners and without any effort, however informal, to invite or permit their participation in the proceedings." 68

Carroll does not completely preclude use of temporary restraining orders to quell campus disorders; it only restricts their use in situations involving conduct protected by the first amendment. The Court stated:

[T] here is a place in our jurisprudence for ex parte issuance, without notice, of temporary restraining orders of short duration; but there is no place within the area of basic freedoms guaranteed by the First Amendment for such orders where no showing is made that it is impossible to serve or to notify the opposing parties and to give them an opportunity to participate. ${ }^{67}$

However, not all campus disorders present substantial first amendment issues, and the blanket prohibition stated above may not apply to those that do not. Particularly if the disorder involves actual violence on campus, an ex parte order may be valid. The injunction in Carroll was issued against recurrence of a rally which only threatened violence; there was no showing of actual violence prior to the order. ${ }^{68}$ Thus, Carroll may not apply in cases of campus violence. In the absence of violence, however, Carroll effectively precludes issuance of ex parte orders, since it is difficult to imagine a situation in which campus authorities would find it impossible to serve process on or notify the opposing party of their intention to seek an injunction.

Nevertheless, Carroll does not prevent college officials from dealing effectively with the threat of campus disorders. Application of Carroll to allow campus demonstrators to appear in court before an injunction is issued does not alter the substantive law concerning the circumstances under which equity will act to prevent injury to persons or property; it merely insures that the demonstrators will have an opportunity to

61 Dilworth v. Riner, 343 F.2d 226, 229 (5th Cir. 1965).

65393 U.S. at 180.

$68 I d$.

67 Id.; see FED. R. CIV. P. 65(b).

The ex parte temporary restraining order is indispensable to the commencement of an action when it is the sole method of preserying a state of affairs in which the court can provide effective final relief.

Developinesits 1060.

6s See 393 U.S. at 176-77. 
present their side of the case before a court may issue an injunction. Carroll thus reemphasizes an earlier recognition by the courts that "[t] he essence of the freedom to speak is the freedom to speak while speech may yet be effective." 69

\section{B. Service of the Injunctive Order}

Another procedural problem is raised in serving the court's order. A fundamental requirement of a temporary or permanent injunction, or of an order to show cause, is actual notice to those against whom the order has issued. ${ }^{70}$ Unless one has notice of an order, he cannot be held in contempt of it. But communicating notice to demonstrators occupying a campus building may be difficult. For example, in Board of Higher Education v. SDS, ${ }^{71}$ the order to show cause and the temporary injunction contained in the order specifically identified certain individuals, but also provided that "all other persons receiving notice of this injunction be and they hereby are restrained and enjoined." 72 In an effort to give widest effect to the injunction, college officials tried to serve a copy of the order, not only on each of the named defendants, but also to others named only as "John Doe" or "Jane Doe." Many of those so served immediately tore up the papers. Seeking an alternative means of service, the president of the college attempted to read the order to the demonstrators over a bullhorn, but was shouted down.

In such a situation, courts should rely on established principles governing service on those refusing to accept process. As stated in one leading case, "[i]t may fairly be said that there is a duty upon persons within the jurisdiction to submit to the service of process." 73

69 Town \& Country Motors, Inc. v. Teamsters Local 328, 355 Mich. 26, 52, 94 N.W.2d 442, 455 (1959).

$70 \mathrm{It}$ is generally necessary to serve process on the person enjoined. See Sorrell v. Superior Court, 73 Cal. App. 2d 194, 166 P.2d 80 (Ct. App. 1946); Coble v. Coble, 229 N.C. 81 , 47 S.E.2d 798 (1948); Pioneer Bldg. \& Loan Ass'n v. Cowan, 123 S.W.2d 726, 730 (Tex. Civ. App. 1938).

7160 Misc. 2d 114, 300 N.Y.S.2d 983 (Sup. Ct. 1969).

72 Note 2 supra. Although actual notice is required, the notice does not have to be by service of process; it is sufficient if the defendant has notice, regardless of the source. See United States v. Onan, 190 F.2d 1 (8th Cir.), cert. denied, 342 U.S. 869 (1951); RCA v. Cable Radio Tube Corp., 66 F.2d 778 (2d Cir. 1933), cert. denied, 290 U.S. 703 (1934); Hill v. United States, 33 F.2d 489 (8th Cir.), cert. denied, 280 U.S. 592 (1929); Mitchell v. Wilkey Gravel Works, Inc., 181 F. Supp. 628 (E.D. Mo. 1959); Walker v. City of Birmingham, 279 Ala. 53, 181 So. $2 \mathrm{~d}$ 493 (1965), aff'd, 388 U.S. 307, reh. denied, 389 U.S. 894 (1967); Pascul v. George Davis \& Co., 170 So. 2d 466 (Fla. Ct. App. 1965); Patten v. Miller, 190 Ga. 152, 8 S.E.2d 786 (1940); American Zine Co. V. Vecera, 338 IIl. App. 523, 88 N.E.2d 116 (1949); Robinson v. Belanger, 332 Mich. 657,52 N.W.2d 538 (1952); Equitable Life Assur. Soc. v. Gex' Estate, 184 Miss. 577, 186 So. 659 (1939); Perlman v. Perlman, 113 N.J. Eq. 3, 165 A. 646 (Ch. 1933); Romero v. Grande Lands, Inc., 288 S.W.2d 907 (Tex. Civ. App. 1956).

73 Gumperz v. Hofmann, 245 App. Div. 622, 624, 283 N.Y.S. 823, 825 (1935), aff'd, 271 N.Y. 544, 2 N.E.2d 687 (1936). 
Following this rule, courts have consistently held that service of process is sufficient if an attempt to serve is made and the physical failure to complete service is due to the refusal of the individual to accept the papers. $^{74}$ To hold otherwise would allow the defendant to control the court's jurisdiction.

\section{Criminal Contempt Proceedings}

Demonstrators who violate an injunctive order may be punished for criminal contempt. Writing for the New York Court of Appeals, Judge Vann ably described this remedy:

An act in willful contempt of a court of justice or its process is an offense against the People of the state. Government by law cannot exist without courts and courts cannot enforce the law unless disobedience of their orders is properly punished. The wrong done to a party by the violation of an order made by a court for his protection is of less importance than the wrong done to the public by obstructing the course of justice and bringing dishonor upon the law itself. This is not a case of mere civil contempt where a fine is imposed mainly to indemnify a party for a private injury, and incidentally to vindicate the authority of the court as an agency of public justice. We are now dealing with a criminal contempt, not in the interest of a party merely, but in the interest of the public, to compel obedience to a lawful mandate of the Supreme Court and to punish resistance thereto as in the nature of a crime. . . . While the court may be set in motion by a person who has been injured, it acts to punish the wrong to the public rather than to redress the private injury. ${ }^{75}$

At the hearing to punish for contempt, the court must first decide whether the alleged contemnors were properly served or otherwise received adequate notice of the injunctive orders. ${ }^{76}$ Assuming it can be proved that a demonstrator violated the injunctive order with knowl-

74 When faced with a situation like that encountered in Board of Higher Educ. v. SDS, 60 Misc. 2d 114, 300 N.Y.S.2d 983 (Sup. Ct. 1969), New York can rely on a wealth of precedent to hold that the failure to serve named defendants is not a bar to criminal contempt proceedings for violation of the injunction, when the failure to complete service is due to the refusal of those defendants to accept service. See Heller v. Levinson, 166 App. Div. 673, 152 N.Y.S. 35 (1915) ; Chernick v. Rodriguez, 2 Misc. 2 d 891, 150 N.Y.S.2d 149 (Sup. Ct. 1956); Martin v. Raffin, 2 Misc. 588, 21 N.Y.S. 1043 (City Ct. 1893).

Refusal to accept service of process may also subject the refusing person to criminal penalties for obstructing justice, either under a specific statutory provision or under the common law. See Putnam v. State, 49 Ark. 449, 5 S.W. 715 (1887); State v. Titus, 152 La. 1011, 95 So. 106 (1922).

75 People ex rel. Stearns v. Marr, 181 N.Y. 463, 466, 74 N.E. 431, 432 (1905) ; see People ex rel. Munsell v. Court of Oyer \& Terminer, 101 N.Y. 245, 248-49, 4 N.E. 259, 260 (1886). See also Beale, Contempt of Court, Criminal and Civil, 21 HARV. L. REv. 161 (1908).

${ }^{76}$ See notes 70-74 supra \& accompanying text. 
edge of its provisions, the court must then decide whether he may be punished if he was not a party to the injunction nor was served with a copy of it. There is authority implying that such a person may be found guilty of contempt where he abets or acts in concert with an enjoined party. In People ex rel. Stearns $v$. Marr 77 an injunction was issued against a union and "each and every member, said defendants and each of them, their agents, servants, representatives and coadjutors and all persons connected with them or either of them [were enjoined] from assaulting, menacing, threatening or intimidating, whether by manner, attitude, speech . . . " any of plaintiff's employees. ${ }^{78}$ Justi- $^{-}$ fying the broad sweep of the injunction, the court stated:

An injunction not only restrains the parties to the action in which it was granted, but also, when so drawn, those who act under or in connection with a party, as attorneys, agents or employees. No person with knowledge of the terms of an injunction, even if not a party himself, can aid or cooperate with a party in doing the prohibited act without incurring the penalty prescribed by statute. Otherwise, in order to make an injunction effective it would be necessary to join every person who could become an agent of a party in violating it. The law is not so tender of those who defy its power and trample upon its command as to exempt them from punishment because they were not named as defendants in the action. ${ }^{79}$

Thus, if Marr is followed, a demonstrator may be held in contempt upon a showing that he had knowledge of the injunction's provisions and acted in concert with an enjoined party in violating them. But this result may be different if the demonstrator (still with knowledge of the injunction's provisions) acts independently in violating the court's order. Judge Learned Hand expressed the traditional rule in Alemite. Manufacturing Corp. v. Staff: ${ }^{80}$

We agree that a person who knowingly assists a defendant in violating an injunction subjects himself to civil as well as criminal proceedings for contempt. This is well settled law. On the other hand no court can make a decree which will bind any one but a party; a court of equity is as much so limited as a court of law; it cannot lawfully enjoin the world

77181 N.Y. 463,74 N.E. 431 (1905).

$78 \mathrm{Id}$. at $465,74 \mathrm{~N} . \mathrm{E}$. at 432 .

79 Id. at 468-69, 74 N.E. at 433 ; see Rigas v. Livingston, 178 N.Y. 20, 24-25, 70 N.E. 107, 108-09 (1904) (by implication). One not named in an injunction was subject to criminal contempt proceedings if he aided or abetted one who was named in violating the order. Since Marr, it has been clear that an individual who aids or abets another in violating a court order is himself guilty of criminal contempt. See Note, Binding Nonparties to Injunction Decrees, 49 MrNN. L. REv. 719, 720 (1965).

80 42 F.2d 832 (2d Cir. 1930). 
at large, no matter how broadly it words its decree. If it assumes to do so, the decree is pro tanto brutum fulmen, and the persons enjoined are free to ignore it. It is not vested with sovereign powers to declare conduct unlawful; its jurisdiction is limited to those over whom it gets personal service, and who therefore can have their day in court. Thus, the only occasion when a person not a party may be punished, is when he has helped to bring about, not merely what the decree has forbidden, because it may have gone too far, but what it has power to forbid, an act of a party. This means that the respondent must either abet the defendant, or must be legally identified with him. ${ }^{81}$

Traditionally, therefore, a person acting independently of other violators could not be punished for disobeying an injunction, even though he had actual knowledge of its provisions. Whether this rule will control in cases involving injunctions against campus disorders has not yet been determined.

A final question arising in criminal contempt proceedings is whether or not a jury trial must be provided. In the federal courts the rule is reasonably clear: Only a sentence of six months or less may be imposed for a criminal contempt conviction without a jury trial. ${ }^{82}$

$81 I d$. at $832-33$ (citations omitted). Much confusion still exists concerning when, if ever, notice of the existence of an injunction is sufficient by itself to bind a person. A related problem is whether the court can attempt to bind the world with its injunctive decree. In Smith v. Swormstedt, 57 U.S. (16 How.) 288, 302 (1853), the Court stated:

The rule is well established, that where the parties interested are numerous, and the suit is for an object common to them all, some of the body may maintain a bill on behalf of themselves and of the others; and a bill may also be maintained against a portion of a numerous body of defendants, representing a common interest.

In Ayres v. Carver, 58 U.S. (17 How.) 591 (1854), the Court again indicated that it would look for a common interest when one party sought to bring an action against a supposedly representative group. Neither of these cases involved injunctions. But, in In re Debs, 158 U.S. 564,570 (1895), the Court applied the concept of common interest to enjoin not only named defendants, but "all persons combining and conspiring with them, and all other persons whomsoever, . . . from in any way or manner interfering with ... any of the business of any of . . the . . . named railroads . . . " It must be pointed out that it is not clear in Debs that the persons held in contempt were not either agents or abettors.

Similar broad injunctions were issued in In re Lennon, 166 U.S. 548 (1897) and Chisolm v. Caines, 121 F. 397 (C.C.D.S.C. 1903). In re Reese, 107 F. 942 (8th Cir. 1901), involved a defendant punished for violating an injunction because he had knowledge of it, although he was not a party, on the theory that the violation amounted to obstructing justice and showed a lack of respect for the dignity of the court.

Judge Hand's decision in Alemite purported to put these earlier decisions to rest. Rule 65 (d) of the Federal Rules of Civil Procedure codifies the Alemite rule:

Every order granting an injunction and every restraining order . . . is

binding only upon the parties to the action, their officers, agents, servants, employees, and attorneys, and upon those persons in active concert or participation with them who receive actual notice by personal service or otherwise.

32 Cheff v. Schnackenberg, 384 U.S. 373, 380 (1966); see Frank v. United States, 395 U.S. 147, 151 (1969); Bloom v. Illinois, 391 U.S. 194, 197 (1968); Duncan v. Louisiana, 391 U.S. 145, 159 (1968). 
When a jury trial must be provided in state court contempt proceedings is less clear. Although the Court stated in Duncan $v$. Louisiana ${ }^{83}$ that, "the Fourteenth Amendment guarantees a right of jury trial in all criminal cases which-were they to be tried in a federal court-would come within the Sixth Amendment's guarantee," 84 this statement does not necessarily mean that a six-month sentence is the maximum that state courts can constitutionally impose in criminal contempt cases without a jury trial. While the Court in Dyke v. Taylor Implement Manufacturing $\mathrm{Co}^{\mathrm{si}}$ indicated that a state court can constitutionally impose sentences of up to six months without a jury trial, the Court in Bloom v. Illinois ${ }^{86}$ did not impose upon the states the requirement that it had imposed upon the federal courts of a jury trial for all criminal contempt sentences over six months. Instead, the Court in Bloom held only that the Constitution guarantees the right to a jury trial in a state court for a criminal contempt punished by a two-year prison term. ${ }^{87}$ The Court's reiteration of its statement in Duncan that it need not settle "the exact location of the line between petty offenses and serious crimes" ${ }^{88}$ seems to indicate a willingness to defer to a state's judgment concerning when a jury trial will be granted. A state may not be required to grant a jury trial in a contempt proceeding even when the possible sentence is longer than six months, as long as it is less than two years.

\section{Conclusion: An Evaluation of the Remedy}

Drawing on well-established principles of equity, courts have made available an effective remedy for college administrators seeking to defuse explosive campus confrontations. To give a troubled campus some protection from destruction and distuption, courts will enjoin a continuing trespass if three elements are present: (1) the probability of irreparable injury; (2) the inadequacy of damages for such injuries as disruption of study and classes; and (3) the inadequacy of a remedy at law to prevent future trespasses. The requirement that these elements be present before an injunction will issue is based on the principle that equity will not act to punish demonstrators, but only to enjoin them from committing harmful acts, whether criminal or not.

83391 U.S. 145 (1968).

84 Id. at 149.

85391 U.S. 216 (1968).

86391 U.S. 194 (1968).

si $I d$. at 211 .

$38 I d$. 
The advantages of injunctive relief are significant. It avoids immediate use of police, allows for a cooling-off period, interjects the courts as mediators, is flexible in application, and has consequences that are not unreasonably harsh. But the remedy is not perfect. If a large number of students violate an injunction, it would be difficult to punish all of them because of the problem of proving that each had adequate notice of the injunction and that each violated its terms. Even if such proof could be adduced, the resulting trial would be very time-consuming. The remedy has thus far been effective because contempt proceedings have been brought only against the leaders of disruptions, and because such proceedings are more expeditious than proceedings in criminal courts.

The future success of the remedy will depend on the good faith of those seeking injunctions and the sound discretion of the courts issuing them. Although injunctions are a drastic remedy, often drafted in broad terms, they are tolerated in part because they are preferable to criminal actions. Yet in some cases ${ }^{89}$ independent criminal proceedings are pending against those also held in contempt for violating an injunction. It is certainly questionable, both from a legal and a sociological point of view, whether a contemnor should be tried in an independent proceeding for acts also forming the basis of a contempt adjudication. It is unlikely that the primary goal of the injunctive process-to restore peace to the campus-is compatible with prosecution in subsequent criminal proceedings. Indeed, the pendency or threat of such prosecution may diminish the effectiveness of courts of equity in dealing with the disorders.

Injunctive relief is not a panacea; it is no more than a sophisticated device to relieve crisis on a campus. The basic problem-dealing effectively with the conditions spawning the turmoil-is not one which our courts alone can solve.

89 In Board of Higher Educ. v. SDS, 60 Misc. 2d 114, 300 N.Y.S.2d 983 (Sup. Ct. 1969), independent criminal proceedings were pending against the defendants at the time that they were sentenced for contempt. On September 23, 1969, many of these same contemnors pleaded guilty in the New York City Criminal Court to charges of criminal trespass in the third degree and jail sentences and fines were imposed upon them. See N.Y. Times, Sept. 26, 1969, at 34, col. 1. 